\title{
Ethics and financial reporting
}

\author{
B. Nossel, Colin Firer* \& J. Ford \\ Graduate School of Business Administration, University of the Witwatersrand, P.O. Box 98, Wits 2050, Republic of South Africa
}

Received June 1993, accepted November 1993

In order to establish the way in which Chartered Accountants in South Africa regard the ethics involved in the presentation and management of reported results, the opinions of a random sample of Chartered Accountants were surveyed. It was found that South African Chartered Accountants appear to be more conservative than their American counterparts and have a different ethical perspective towards financial reporting. In general, auditors were found to be slightly more ethical than Chartered Accountants in industry and commerce. Two thirds of the respondents also indicated that they had encountered a significant amount of unethical practice in the preparation of financial statements.

\begin{abstract}
Om vas te stel hoe Geoktrooieerde Rekenmeesters in Suid-Afrika die etiese vraagstukke in die aanbieding en bestuur van gerapporteerde resultate beskou, is die menings van ' $n$ toevalmonster van rekenmeesters ondersoek. Daar is bevind dat Suid-Afrikaanse rekenmeesters blykbaar meer konserwatief as hulle Amerikaanse ewekniex is en 'n ander etiese perspektief ten opsigte van finansiële beriggewing het. Oor die algemeen is gevind dat ouditeure effens meer eties was as rekenmeesters in die nywerheid en handel. Twee-derdes van die respondente het aangedui dat hulle ' $n$ betekenisvolle hoeveelheid onetiese praktyke in die voorbereiding van finansiële state teěgekom het.
\end{abstract}

*To whom correspondence should be addressed.

'And the truth isn't what you want to see. In the dark it is easy to pretend that the truth is what it ought to be' (C. Hart \& R. Stilgoe: Phantom of the Opera).

The word ethical is derived from the Greek word 'ethos' which means both 'character' and 'sentiment of the community', or culture (Bhide \& Stevenson, 1990). Ethical has to do with a general understanding of right and wrong in the attitudes and actions of individuals and within the communities (institutions) of which they are part. According to Webster's dictionary ethics are defined as:

'the study of standards of conduct and moral judgement; the systematic study of the principles and methods for distinguishing right from wrong, and good from bad' (1970: 285).

Stanford (1991: 103) however notes that terms such as right and wrong, good and bad are based on values, which means that precise, universal definitions can be elusive. Carr (1968: 59), on the other hand, took a controversial standpoint when he defined business ethics as being the 'rules' by which the 'game' of business is played. He maintains that no-one should think any the worse of the game of business because its standards of right and wrong differ from the prevailing traditions of morality in society.

Carey proposed that a code of professional ethics is essentially a

'set of rules and precepts designed to induce an atuitude and a kind of behaviour on the practitioners of the profession concerned, which will encourage public confidence' (1978: 86).

Every profession has a built-in code of ethics to compel ethical behaviour in its members (Greenwood, 1978; Burns \& Haga, 1977). These codes assist individuals when they face ethical dilemmas and problems of 'weakness of will'.

Loeb (1978) and Abott (1983) describe professional ethics as having a dual role. They have both philosophical and social implications. The philosophical aspect involves questions of morality, what is right and what is wrong, whereas the sociological perspective is concemed with the question of professional self-regulation and control. The former deals with moral action, encompassing a 'sense of duty' to society. The latter is needed because society grants a profession the exclusive right to perform certain tasks within the bounds of the profession.

Capital markets depend on reliable financial information in allocating scarce resources (Chua \& Mathews, 1990: 7). Financial statements are the primary source of such financial information. Financial accountants as well as independent auditors, who produce and certify such statements, should be committed to upholding both technical and ethical standards of conduct.

Reed (1985) argues that the accounting profession, since the 1970s, has been affected by the general competitiveness in the business environment. This, he asserts, has placed members of the auditing profession, as well as accountants in commerce and industry, in positions where integrity and professional standards may be put under pressure.

Norval (1992), maintains that with the recent downtum in the South African economy, financial accountants and auditors have been experiencing increasing pressure to present their organization's financial position in the most favourable light. An article by Bruce (1991) suggests that Chartered Accountants are pressured into taking a relaxed view of slow-moving stocks, an optimistic view of bad debts, and into changing the basis of accounting without informing the company's bankers.

The relatively short tenure for chief executive officers, (five to ten years in many large companies), creates a shortrun perspective of corporate objectives and emphasizes maximizing short-run profits. This may well result in the emergence of creative accounting practices. According to $\mathrm{Ng}$ (1989: 1), creative accounting is not a new phenomenon. Elements of creative accounting can be found as early as the nineteenth century, initially in the form of income smoothing and later through the creation of secret research. The $a b-$ sence of accounting standards and legislation in the early days meant that creativity was necessary in the development 
of accounting as new business methods and structures emerged. The current prevalence of creative accounting methods has prompted writers like Griffiths (1986: 1) to comment that in the United Kingdom 'Every company in the country is fiddling its profits.... Any accountant worth his salt may confirm that this is no wild assertion'.

Griffiths believes that this situation arises from the flexibility and vagueness of the accounting rules that govern the way financial statements should be prepared and presented.

Davis (1989: 67) maintains that the corporate game plan is to maintain a steadily rising eamings-per-share that will stimulate demand for shares, thus raising the share price. Most businesses attempt to report their income as fairly as possible while still meeting their own requirements, taking advantage of any gaps in reporting standards which will allow management to present a slightly better picture. This results in creative accounting.

Creative accounting takes on many forms. According to Smith (1992), companies can make use of the following twelve accounting techniques involving subjective judgement, the objective of which is to make a company's financial figures look better than they actually are:

1. Pre-acquisition write-downs

2. Disposals

3. Deferred considerations

4. Extraordinary and exceptional items

5. Off-balance-sheet finance

6. Contingent liabilities

7. Capitalization of costs

8. Brand accounting

9. Changes in depreciation policy

10. Convertibles with put options

11. Pension-fund accounting

12. Currency mismatching

Bosch (1987: 47) outlined five main reasons why accountants should resist creative accounting, namely:

1. It misleads investors and distorts business judgements.

2. The Institute lays down the obligation to report ethically.

3. The credibility of the business community will be undermined.

4. Free enterprise is only kept alive through objective company accounts.

5. The benefits of creative accounting are short term.

Accountants are expected to adhere to personal standards that are enforced by their Code of Professional Conduct. However ethical standards do not spontaneousy instill morality in professional members. Nonetheless, they provide honest good-intentioned individuals with a basis for their decisions and actions. They also discourage those who use unethical practices because codes render it easier to detect such practices.

Financial managers who take unproductive actions to boost short-term earnings may be acting completely within the laws and rules. They may also be acting in the best interest of the corporation. However, if they fail to consider the adverse effects of their actions on other stakeholders, they are acting unethically. According to Lewicki \& Litterer (1985: 319), financial managers are faced with three major ethical questions in evaluating the way to behave in ethical dilemmas: means-ends, relativism, and truth-telling.
Means-ends questions arise from a manager's desire to use ethically marginal tactics in order to accomplish objectives. Such choices are more likely to be made when managers are strongly profit-oriented, or the competition is fierce.

Questions of relativism arise when managers must determine the appropriate criteria which will dictate ethical standards. The greater managers' leaning towards ethical relativism, the more they will look to their personal values to dictate the way they should behave. The greater the predisposition toward an absolutist perspective, the more they will turn to established moral and ethical codes to direct their behaviour.

Truth-telling questions arise when managers must consider whether to deviate from telling the truth in order to achieve their objectives. Standards of truth-telling help to define what communication is ethical or unethical. Carr, for example, argued that

'Strategy in business is analogous to strategy in a game of poker. Short of outright cheating, business ought to play its game as poker players do' (1968: 144).

Financial managers and accountants can justify their manipulation of earnings in financial reporting by looking at them from a truth-telling moral standpoint. According to Carr this behaviour is legitimate. It is here that adhering to a strict code of ethical conduct is necessary to force ethics in financial reporting.

\section{Significant prior research}

Baumhart (1961) researched the attitudes towards ethics of subscribers to the Harvard Business Review. The 1500 responses he received indicated that:

- Executives were aware of the social responsibilities of business. They viewed the corporation as a human grouping of the larger society in which it functions.

- Most people felt that the person most likely to be ethical in business was the person with a well defined personal code of ethics.

- Executives conceded that there were numerous practices in their industries which were considered acceptable, but which they regarded as unethical.

- Older executives were found to have a more favourable attitude towards ethics, and professed to having higher standards than their younger counterparts.

- The majority of executives polled said that they would welcome an attempt to introduce a written code of ethics into their industries.

- Executives believed that if unethical practices were to be reduced, top management would have to lead the way.

- The most significant factor influencing the behaviour of people in the work context was the behaviour of their superiors.

Baumhart found that there were not significant differences in attitudes towards ethics across different levels of management and different industries. Overall most respondents acknowledged the importance of ethics in business and the need to ensure sound ethical practices and norms.

Webley (1971) polled members of the British Institute of Directors. They did not seem to experience a basic conflict between the demands of their managerial careers and their 
ethical standards. Findings which corresponded to Baumhart's were that older businessmen had higher ethical standards than younger respondents, and that the majority of respondents favoured ethical codes. Brenner \& Hollander (1976) found that there was a slight decline in ethical standards over the 15-year period since the Baumhart study.

A survey of its subscribers across 16 countries was undertaken by International Management Magazine (1983), 53\% of the respondents had faced ethical conflict between the demands of their companies and their personal beliefs. The most common unethical practices were irregular payments and bribes.

A study done by Allen (1980), in which people from a wide range of organizations were polled, revealed that $65 \%$ of those questioned felt that organizations tended to make their employees behave dishonestly. Carroll (1978), surveying business executives from three managerial levels across industries, found that pressure from top management may cause people to transgress their own ethical standards.

O'Flaherty (1983) conducted a pilot study to establish general trends among South African business people regarding ethics in business. He found that:

- No significant relationships were found to exist between attitudes of business people to business ethics and the variables pertaining to age, functional area and industry.

- No clear, universal understanding of the concept of business ethics was found.

- People felt that overall more advantages were gained from behaving ethically.

- Personal standards or codes were felt to be important in determining one's ethical behaviour in business. The influence of superiors and formal company policy were also seen as important factors.

A survey done by Bruns \& Merchant (1990: 22) illustrated managers' attitudes towards earnings management in the United States. A questionnaire describing 13 eamingsmanagement situations was responded to by 649 managers. The following generalizations can be made from their findings:

1. Respondents viewed the management of earnings by accounting methods as less acceptable than by manipulating operating decisions.

2. Increasing earnings was judged less acceptable than reducing earnings.

3. Materiality mattered. Eamings management was considered less acceptable if the earnings effect was large.

4. The time period affected ethical judgements. Managing earnings at the end of a quarterly period was viewed as being more acceptable than at the end of an annual period.

5. The method of managing earnings also had an effect on the ethical attitudes. Increasing profits by offering extended credit terms was seen as less acceptable than accomplishing the same end by selling excess assets or using overtime to increase shipments.

In practice it appeared that a large majority of managers used at least some method to manage eamings which, although legal, may not have been strictly ethical. These actions are questionable because they involve deceptions that are not disclosed. Two of the major problems identified were the high tolerance for operating manipulations and conflicting management views on which practices are moral and/or ethical. The results indicated the need for clearer accounting and operating standards for accountants.

The review of the literature indicated that very little work had been done on the topic of business ethics in the South African arena, and no work was located on ethics in financial reporting in South Africa.

\section{Objectlves of the research}

The objective of this article was to explore financial managers' and auditors' attitudes towards the ethics involved in financial reporting practices.

The following research questions were addressed:

1. How do the ethical attitudes towards eamings management of South African Chartered Accountants compare to those of the United States?

2. Do Chartered Accountants in auditing have a more ethical focus than Chartered Accountants in industry and commerce?

3. Do Chartered Accountants in public companies have higher ethical values than those in private and other companies?

4. Do Chantered Accountants' attitudes towards ethics differ in different industries?

5. Do demographics such as position in the organization, time period qualified, language spoken, and size of company have an effect on ethical attitudes?

6. Is the Accounting Code of Professional Conduct a sufficient mechanism to ensure the maintenance of ethical standards?

\section{Research methodology}

A questionnaire, based on the United States research of Bruns \& Merchant (1990) was developed.

- The first section of the questionnaire, which dealt with management accounting issues, was almost identical to the United States questionnaire, with the exception of terminology which was changed to suit the South African accounting environment.

- The second section asked financial accounting-related questions which were derived from the literature reviewed on creative accounting.

- In addition, demographic information about respondents and their companies was requested. Respondents' views on ethics and the adequacy of the Accounting Code of Professional Conduct as a mechanism to ensure ethical conduct in South Africa were elicited. The questionnaire was issued in both official languages.

The questionnaire was evaluated by holding structured interviews with accounting academics, an officer of the Institute of Chartered Accountants, technical partners of accounting firms and Chartered Accountants in commerce and industry.

In the third phase, the instrument was pre-tested on a sample of five Chartered Accountants. The objective of the pre-test was to identify possible errors, ambiguities or misunderstandings within the questionnaire.

A sample of 750 Chartered Accountants was selected from the membership list of the Institute of Chartered Accountants. This list comprises 13000 registered members 
throughout South Africa. Every seventeenth member was selected from the total list for inclusion in the sample. The sample was made up of English- and Afrikaans-speaking Chartered Accountants. The questionnaire was mailed because it was felt that face to face interviews may be threatening to respondents who might be less inclined to total honesty of reponse, and because a country-wide sample was sought.

The questionnaire (the second section of which is reproduced in Appendix 1) reflected everyday ethical choices facing financial managers. Respondents were asked to evaluate a series of hypothetical examples, using a fivepoint Likert scale, to indicate whether they believed that the situations described indicated:

- ethical behaviour (completely professional behaviour);

-questionable behaviour (which would make one feel uncomfortable);

- a minor infraction (where the financial manager would be warned not to do it again);

- a serious infraction (the financial manager would be seriously reprimanded); or

- totally unethical behaviour (which would result in the financial manager being fired).

In order to ensure that the questionnaire could be completed in a short period of time, most of the questions were closed-ended. The sensitivity of the subject matter was addressed when structuring the questionnaire. Respondents were assured of complete confidentiality and were told that their responses were to be analyzed in aggregate to ensure anonymity. Names and company details were not requested.

The five-point Likert scale was rescaled from ordinal to interval data using Correspondence Analysis. The new fivepoint scale values were used to transform the original data file. A Chi-Squared Goodness of Fit Test was used to determine whether the responses of Chartered Accountants in South Africa were the same as those of the United States.

The South African data was regrouped from five to three categories (ethical; questionable/minor infraction; serious infraction/unethical) to bring them into line with the United States data. The critical Chi-Square value was calculated at two degrees of freedom (as there were three categories), and at a 5\% significance level. The observed data comprised the frequencies for each of three ethical categories obtained from the South African study. The expected data comprised the United States frequencies in each ethical category obtained by multiplying the United States percentages by the number of respondents in the South African sample.

T-tests were used to test all hypotheses which involved a comparison between the means of two groups. Altogether 95\% confidence levels were used. The assumption was made that the two populations were normally distributed. All data was tested for the assumption of equal variance before running the T-tests. Analysis of Variance (ANOVA) was performed to test the hypotheses where the means of more than two groupings were compared.

It should be noted that the South African sample was made up of 113 respondents, whereas the United States sample contained 649 respondents. The South African sample was made up of only Chartered Accountants, whereas the United States sample was made up of general managers and finance, control and audit managers.
Table 1 Position of respondents

\begin{tabular}{lc}
\hline Position & \% Sample \\
\hline Audit partner & $15 \%$ \\
Auditor & $14 \%$ \\
Financial manager & $22 \%$ \\
Managing director & $12 \%$ \\
Financial director & $8 \%$ \\
Sole practitioner & $4 \%$ \\
Financial accountant & 15 \\
Tax advisor & $4 \%$ \\
IT manager & $2 \%$ \\
No response & $5 \%$ \\
\hline
\end{tabular}

Table 2 Sector in commerce and industry

\begin{tabular}{lr}
\hline Manufacturing & $27 \%$ \\
Retail & $10 \%$ \\
Service & $19 \%$ \\
Mining & $1 \%$ \\
Other & $12 \%$ \\
Auditing & $31 \%$ \\
\hline
\end{tabular}

\section{Results}

The return of 113 questionnaires out of the 750 sent out, represented a $15 \%$ response rate. Of the replies received $76 \%$ were from English speakers and 24\% from Afrikaans speakers. The auditing profession provided $31 \%$ of the respondents and $69 \%$ were in industry and commerce. Reflected in Table 1 are the reported positions of the respondents and shown in Table 2 the distribution of respondents by the sector in which their organizations operate.

Of the respondents $17 \%$ had been qualified for less than 5 years, $52 \%$ for between 5 and 20 years and $31 \%$ for more than 20 years. Public companies/organizations employed $31 \%, 35 \%$ were employed by private companies and $4 \%$ by close corporations.

Organizations with tumovers of less than R 10 million per annum accounted for $27 \%$ of the responses, $30 \%$ to organizations turning over between R10 million and R100 million per annum and $42 \%$ to organizations with sales volumes in excess of R100 million.

In Table 3 the views of respondents on their experience of unethical behaviour in practice, and on their views on the Accounting Code of Professional Conduct, are reported.

Chartered Accountants appear to be encountering a significant amount of unethical practice in financial reporting, with $65 \%$ of the respondents admitting having witnessed such behaviour. Only just over half of the respondents believed that the Accounting Professional Code was sufficient to prevent unethical behaviour. Of those who did not believe the Code was adequate, 39\% felt that a Code of Ethical Conduct for accountants is required in South Africa, as opposed to $15 \%$ who did not think it was necessary.

In Table 4, the responses of the South African and United States respondents to the ethical dilemmas posed in the questionnaires, are summarized. 
Table 3 Views on the accounting code of professional conduct

\begin{tabular}{lllll}
\hline & Yes & No & $\begin{array}{c}\text { No } \\
\text { response }\end{array}$ \\
\hline $\begin{array}{l}\text { Have you experienced unethical behaviour in } \\
\text { actual practice? }\end{array}$ & $65 \%$ & $30 \%$ & $5 \%$ \\
$\begin{array}{l}\text { Do you consider the Accounting Code sufficient } \\
\text { lo prevent unethical behaviour in accounting? }\end{array}$ & $56 \%$ & $40 \%$ & $4 \%$ \\
$\begin{array}{l}\text { If not, do you think a code of ethical conduct for } \\
\text { accountants is required in SA? }\end{array}$ & $39 \%$ & $15 \%$ & $46 \%$ \\
\hline
\end{tabular}

Table 4 South African versus United States results

\begin{tabular}{|c|c|c|c|c|c|c|}
\hline & \multicolumn{2}{|c|}{ Ethical } & \multicolumn{2}{|c|}{ Questionable } & \multicolumn{2}{|c|}{$\begin{array}{c}\text { Unethical } \\
\text { Serious }\end{array}$} \\
\hline \multicolumn{7}{|c|}{ Manipulating operating decisions } \\
\hline Result to reduce eamings & $22 \%$ & $79 \%$ & $45 \%$ & $19 \%$ & $33 \%$ & $2 \%$ \\
\hline Result to increase eamings & $12 \%$ & $57 \%$ & $47 \%$ & $31 \%$ & $40 \%$ & $12 \%$ \\
\hline \multicolumn{7}{|c|}{ Manipulating accounting methods } \\
\hline Change to eamings small & $5 \%$ & $5 \%$ & $51 \%$ & $45 \%$ & $43 \%$ & $50 \%$ \\
\hline Change to eamings large & $1 \%$ & $3 \%$ & $20 \%$ & $21 \%$ & $79 \%$ & $76 \%$ \\
\hline \multicolumn{7}{|c|}{ Deferring discretionary expenditure } \\
\hline \multicolumn{7}{|c|}{ Meet an interm quarterly } \\
\hline budget & $1 \%$ & $47 \%$ & $36 \%$ & $41 \%$ & $63 \%$ & $12 \%$ \\
\hline Meet an annual budget target & $4 \%$ & $41 \%$ & $13 \%$ & $35 \%$ & $83 \%$ & $24 \%$ \\
\hline \multicolumn{7}{|c|}{ Increasing earnings to meet budget target } \\
\hline \multicolumn{7}{|c|}{ Selling fixed assets to realize } \\
\hline a profit & $15 \%$ & $\mathbf{8 0 \%}$ & $32 \%$ & $16 \%$ & $52 \%$ & $4 \%$ \\
\hline \multicolumn{7}{|l|}{ Ordering manufacturer to } \\
\hline work overtime & $79 \%$ & $74 \%$ & $15 \%$ & $21 \%$ & $4 \%$ & $5 \%$ \\
\hline \multicolumn{7}{|l|}{ Offering liberal sales payment } \\
\hline terms & $34 \%$ & $43 \%$ & $43 \%$ & $44 \%$ & $23 \%$ & $15 \%$ \\
\hline
\end{tabular}

The South African Chartered Accountants appear to be more ethical than their United States counterparts, as the Americans consider more of the earnings management situations ethical than do the South Africans.

The results for each question were as follows:

\section{Manipulating operating decisions}

South African respondents considered it questionable or unethical to use such practices to reduce or increase earnings. They did, however, consider it slightly more ethical if the result was to reduce earnings rather than to increase earnings. The Americans considered the manipulation of operating decisions ethical, but less so where the result was to increase earnings.

Whether the result of the manipulation was to reduce or increase earnings, the null hypothesis that ethical attitudes in SA and the USA are the same, was rejected. Thus, it can be concluded that South African Chartered Accountants viewed the manipulation of operating decisions as less acceptable than their American counterparts.

\section{Manipulating accounting methods}

Both the South African and the United States respondents considered manipulating accounting methods unethical. Materiality mattered as earnings management was considered less acceptable if the effect was large rather than small.

Whether the change to earnings was either small or large, no significant difference could be detected in the attitudes of South African Chartered Accountants and United States financial managers towards the ethics of manipulating accounting methods.

\section{Deferring discretionary expenditure}

Deferring discretionary expenditure was considered unethical by the South African Chartered Accountants, more so in order to meet an annual budget target than a quarterly target. Thus, the time period of the effect may affect ethical judgements.

The American financial managers considered this practice ethical or questionable. They also felt it was more unethical to defer expenditure in order to meet an annual budget target rather than a quarterly target.

For the deferral of annual as well as quarterly discretionary expenditure, the chi-square test indicated that ethical attitudes in South Africa are different from those in the United States, with the South Africans viewing this practice as more unethical than their American counterparts.

\section{Increasing earnings to meet budget}

(a) Selling fixed assets to realize a profit was considered unethical or questionable by the South African respondents. The American study, however, showed that a very high proportion of their sample considered this ethical. This was considered the most unethical of the situations by the South Africans, and the least unethical by the Americans.

Here the null hypothesis of similar ethical attitudes was rejected, suggesting that there is a significant difference in ethical attitudes between South Africa and the United States regarding this practice.

(b) Ordering manufacturing to work overtime was regarded as ethical by both the South African and the American respondents. The null hypothesis could not be rejected here.

(c) Offering liberal sales payment terms in order to increase earnings was judged questionable by the South African Chartered Accountants, and questionable/ethical by the American financial managers. The Americans considered this the most unethical of the practices mentioned in the questionnaire. Again using the chi-square test, the null hypothesis could not be rejected.

Overall the South Africans appear to have higher ethical standards when it comes to financial reporting. This may be attributed to a stronger professional code in the Commonwealth and ex-Commonwealth countries.

A further aim of the study was to evaluate the impact of certain variables on attitudes towards ethics. These variables could be divided into two groups:

1. the independent variables:

i.e. whether respondents employed in auditing/industry 
or in commerce; in public or private and other companies; and the type of industry in which they were employed.

2. the demographic variables:

the language spoken, the position in the company, the size of the employer company and the length of time respondents had been qualified.

There was very little difference between the ethical attitudes of Chartered Accountants in auditing and those employed in commerce and industry. Only in the case of 2 of the 17 questions posed (namely, recording pre-paid expenses as current when the firm is likely to exceed its budgeted profits; and using off-balance sheet finance to display a lower gearing) could the hypothesis that the two groups of respondents held similar views be rejected. Of the remaining 15 responses, the mean responses of those employed in the auditing profession were greater than their commercial counterparts (although not significantly so) in 11 instances. It may be concluded that accountants in auditing were slightly more ethical, perhaps as a result of the position they fulfil as auditors.

No difference in ethical responses could be detected, based on type of company or industry in which the respondents were employed. These results were not surprising as ethical attitudes are generally intrinsic and based on an individual's personal value system, not on extemal variables.

Language spoken, position and length of time since qualification had no effect on ethical attitudes. However, size seemed to have some influence as accountants in companies with a turnover greater than R100 million were shown to display more ethical views on two of the issues (namely creating a maintenance provision for expenditure due to be incurred in the following year when profits are ahead of budget and using off-balance sheet financing to display a lower gearing) than the small and medium sized companies.

Comparing these findings to prior research done it may be noted that:

- Baumhart (1961) found that there were no significant differences in attitudes towards ethics across different levels of management and across industries. However, he found older executives to have higher ethical standards than their younger counterparts.

- England (1978) found that type of industry was not related to values. However, organizational size and manager's age are factors which relate to values.

- Boshoff, Smith, Moore \& Rautenbach (1986) found consistency in the value profiles of managers from different economic sectors, hierarchical and achievement levels as well as age groups.

- O'Flaherty (1983) found no significant relationships between attitudes towards business ethics and the variables pertaining to age, functional area and industry.

- Jersky (1991) found language to be statistically significant with respect to ethical attitudes.

Thus, the present findings are consistent with past studies done with respect to the independent variables, type of company and industry. Where the demographic variables are concerned, past research has found seniority, language and organizational size to have some effect on ethical attitudes. This was not found to be the case in this research.

\section{Conclusions}

The main findings of the research can be summarized as follows:

1. On comparing the South African results to those of the United States, the South African Chartered Accountants were found to be more conservative in financial reporting. Their approach towards ethics in financial reporting is of a higher standard than that of the United States, and of a similar standard to that of the United Kingdom and Australia.

2. The independent variables, type of company and industry had no effect on ethical attitudes. Auditors were slightly more ethical than Chartered Accountants in industry and commerce. None of the demographic variables had any effect on ethical attitudes.

3. The Accounting Code of Professional Conduct was considered questionable as a mechanism to prevent unethical behaviour. More than one third of the sample favoured the implementation of a Code of Ethical Conduct for Accountants in South Africa.

Recommendations for improving the standard of ethical behaviour in South Africa include the following:

1. Ethics in accounting need to be institutionalized and taught from the education stage to ensure that the young accountants accept ethics as second nature.

2. As an incentive to report ethically, corporate ethical standards should be compared and publicized. Companies should be rated according to the number of questionable accounting practices they perform, as has recently been done in the United Kingdom by Smith (1992).

3. A value should be attached to quality reporting. Emphasis should be placed on accuracy as opposed to good results. The pressure on results of the shareholders, creditors, the board and the CEO should be removed.

4. Commence and industry need to become involved in their own code of ethical conduch, which should be implemented to ensure that there are ethics right across the board.

5. An ethical monitoring group, such as the Industrial Members' Ethical Advisory Committee (IMEAC) which has been set up in the United Kingdom to deal with ethical issues in Accounting, should be established in South Africa. This will act as backing for the Accounting Code of Professional Conduct to ensure that ethical behaviour is sanctioned.

As Peter Wrighton (1992) of the Premier Group said in his address at the Wits Business School Graduation Dinner:

'The health of a business environment is a function of the moral climate in which the business is conducted. Foreign perception of the moral climate of South African business has been negative for a long time now. Present visions of the New South Africa spanning the gap between first and third world economies, are short on images of efficiency, productivity, counesy and high moral standards. To encourage foreign investment, South African business must communicate its commitment to high standards of business ethics. Executives and employees of corporations need to be 
assisted to deal effectively with the conflicts between moral values and botwm line performance. The high performers need to be perceived as having high standards of business ethics'.

\section{References}

Abboth, A. 1983. 'Professional ethics', American Journal of Sociology, Vol. 88, No. 5: 855-885.

Adair, J. 1980. Management and morality. London: Gower. Allen, F.T. 1976. 'Corporate morality: executive responsibility', Atlanta Economic Review, May/June, pp.8-11.

Baumhar, R.C. 1961. 'How ethical are businessmen?', Harvard Business Review, July-Aug. Harvard Business Review Reprints, pp.37-50.

Bhide, A. \& Stevenson, H. 1990. 'Why be honest if honesty doesn't pay', Harvard Business Review, September-October 1990, pp.121-129.

Bosch H. 1987. 'Creative accounting', The Chartered Accountant in Australia, May, pp,42-48.

Brenner. E.A. 1977. 'Is the ethics of business changing?', Harvard Business Review, Jan-Feb, pp.51-71.

Bruce, R. 1991. 'Facing up to ethical dilemmas', Accountancy Age, September 19.

Bruns, W.J. \& Merchant, K.A. 1990. 'The dangerous morality of managing earnings', Management Accounting, August, pp.22-25.

Burgen, C. 1976. 'How companies react to the ethics crisis', Business Week, February 9. pp.78-79.

Burns, D.C. \& Haga, W.J. 1977. 'Much ado about professionalism: a second look at accounting', Accounting Review, Vol. 52, No. 3: 705-715.

Carey, J.L. 1978. 'The realities of professional ethics'. In Loeb, S.E., Ethics in the accounting profession. Santa Barbara: Wiley \& Sons, pp.85-92.

Carr, A.Z. 1968. 'Is business bluffing ethical', Harvard Business Review, Jan-Feb, pp.143-153.

Carroll, A.B. 1978. 'Linking business ethics to behaviour in organisations', Advanced Management Journal. Summer, Vol. 43, No. 3: 4-11.

Chua, F.C. \& Mathews, M.R. 1990. Professional ethics, public confidence and accounting education. Discussion Paper Series, Department of Accountancy, Massey University, New Zealand.

Davis, J.R. 1989. 'Ambiguity, ethics, and the bottom line. Business Horizons, May-June, pp.65-70.

England, G.W. 1978. 'Managers and their value systems: a fivecountry comparative study', Columbia Journal of World Business. Summer, pp.35-44.

Greenwood, E. 1978. 'Attributes of a profession'. In Loeb, S.E., Ethics in the accounting profession. Santa Barbara: Wiley \& Sons, pp.49-62.

Griffiths, I. 1986. Creative accounsing: How to make your profits what you want them to be. London: Unwin Paperbacks. London. International Management Magazine, Survey on Corporate Ethics, Feb. 1983. Vol 38, No. 2: 40-43.

Jersky, H. 1991. An analysis of business ethics in South Africa within philosophical frameworks. Johannesburg: University of the Witwatersrand, MBA Research Report.

Lewicki, R.J. \& Litterer, J.A. 1985. Negotiation. Illinois: Irwin.

Loeb, S.E. 1978. Eshics in the accounting profession. Santa Barbara: Wiley \& Sons.

$\mathrm{Ng}$, L.W. 1989. Creative accounting. Discussion Paper Series, Department of Accountancy, Massey University, New Zealand.
Norval, L.R. 1992. 'Business ethics', Editorial in Accounting SA, March, p.59.

O'Flaherty, C.M. 1983. Ethics and the South African businessman: a pilot study. Johannesburg, University of Witwatersrand: Research Report.

Reed, R.O. 1985. 'An American accounting dilemma: professionalism vs commercialism', The Chartered Accountant in Aus. tralia, pp.18-20.

Smith, T. 1992. Accounting for growth. London: Century Business.

Stanford, S.E. 1991. 'Ethics', Internal Auditor, June, pp.102-104.

Webley, S. 1971. In Adair, J. 1980. Management and morality. London, Gower, p.115.

Webster's Seventh New College Dictionary. 1970. London: G. Bell \& Sons, London.

Wrighton, P. 1992. Address to the Wits Business School Graduation Dinner.

\section{Appondix 1 Extract from questionnaire}

The following questions reflect everyday ethical choices facing financial managers. Please evaluate these hypothetical examples using the following scale to indicate how you judge their acceptability.

1. Ethical. Completely professional.

2. Questionable. Would not say anything to the financial manager but makes one feel uncomfortable.

3. Minor infraction. The financial manager should be wamed not to do it again.

4. Serious infraction. The financial manager should be seriously reprimanded.

5. Totally unethical. The financial manager should be fired.

1. The company's headquarters building is scheduled to be painted in 1993. But since profit performance is way ahead of budget in 1992, the financial manager has sug. gested that a maintenance provision be created in 1992 for this cost. How ethical is this behaviour?

2. The financial manager has ordered the employees not to submit their expenditure vouchers (e.g. travel, advertising, maintenance) until the next accounting period, so that the company can make its budgeted profit targets.

a) The expenses were postponed from February and March until April in order to make the first quarter target. How ethical is this deferral?

b) The year-end is in December. The expenses were postponed from November and December until January in order to make the annual target. How ethical is this deferral?

3. A small amount of office supplies was accidentally ordered and delivered in December when the general manager had ordered that no discretionary expenses be incurred for the remainder of the fiscal year. According to company policy, office supplies are to be recorded as an expense when delivered. To correct the mistake the financial manager asked the accounting department not to record the invoice until February. How ethical is this of the financial manager?

4. In order to improve performance to meet budget targets, the financial manager performed the following tasks? 
a) He decided to implement a sales programme offering liberal payment terms to pull some sales that would normally occur next year into the current year; customers accepting delivery in the fourth quarter would not have to pay the invoice for 120 days. How ethical is this?

b) He ordered manufacturing to work overtime in December so that everything possible could be shipped by the end of the year. How ethical is this?

c) He sold fixed assets only for the purpose of realizing a profit to improve performance. How ethical is this?

5. In December the general manager realized the company would exceed its budgeted profit targets for the year.

a) He ordered the financial manager to prepay some expenses for a major trade show to be held the following year and to record them as current year expenses. How ethical is it for the financial manager to do this?

b) He ordered the financial manager to develop a rationale for increasing the provision for inventory obsolescence. The financial manager was able to identify a large amount of finished goods that conservative accounting would say could be written off, even though he knew they would later be sold at close to full price. How ethical is it for the financial manager to do this?

6. The company sold most of the inventory that had been written-off the previous year, and a customer indicated some interest in buying the rest the following year. The financial manager agreed to prepare a rationale for $r e$ ducing the provision for inventory obsolescence. His motivation for recapturing the profit was:

a) To be able to continue working on some important product development projects that might have been delayed due to budget constraints. How ethical is this behaviour?

b) To make budgeted profit targets. How ethical is this?
7. In November the company was straining to meet budget. The financial manager requested of a consulting firm that was doing work for the company that the firm not send an invoice until the following year. The partner agreed.

a) How ethical is this practice if the amount is small?

b) How ethical is this practice if the amount is large?

8. The financial manager knows that the stock market prefers a smooth growth in earnings to fluctuating operational performance. He therefore ensures that those fluctuations are removed by building up substantial reserves in good years to enable eamings to be bolstered in less profitable years. How ethical is it for the financial manager to smooth operating profits?

9. The company's results are poor this year. The financial manager realizes that a few of the sure investments of a few years back are ruming out of steam. He decides to lake a big decrease in earnings this year and get the losses behind him. How ethical is it for the financial manager to do this?

10. The financial manager discovers that one overseas division has made an uncharacteristic loss of a million rand. He tells the chaiman who says: 'That is an extraordinary item! Let's hope it doesn't happen again'. Later he discovers that another overseas division has made an uncharacteristic profit of a million rand. The chairman's response is, 'What an exceptional performance. Let's hope they keep it up'. How ethical is it to report all big losses as extraordinary and below the line, and all big profits as exceptional and above the line in order to boost eamings per share?

11. The financial manager uses methods of raising funds without reflecting those borrowings on the balance sheet by using off balance sheet financing. This enables him to reduce the company's gearing and to secure funding which would otherwise not have been available. How ethical is this behaviour? 